\title{
硝酸塩の投与が反蜀動物の飼料消化率および第一胃内 微生物によるセルロース分解能汇及ぼす影響
}

\author{
宮崎 昭・岡本和夫・津田栄三・川島良治・上坂章次 \\ 京都大学農学部, 京都㸝 606 \\ (1973.9. 25 受付)
}

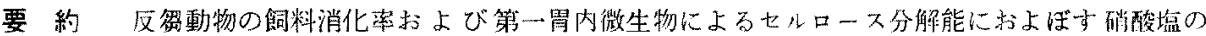

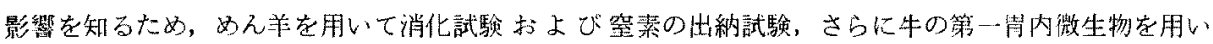

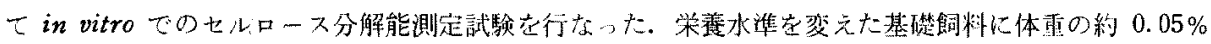

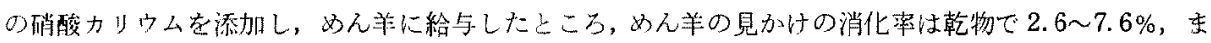

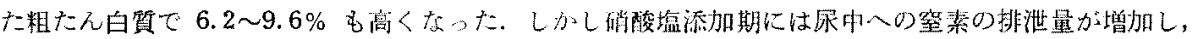
掑取された筀素の利用性は，硝酸塩添加によ。てとくによくなるということはなかった，その他の成分

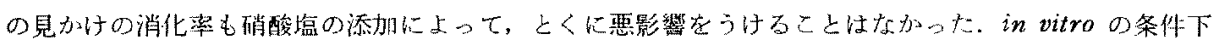
で恃，第一胃内微生物による 24 時間培養によるセルロース分解率は，硝酸態䇪素 $8 \mathrm{ppm}$ 以上で低下

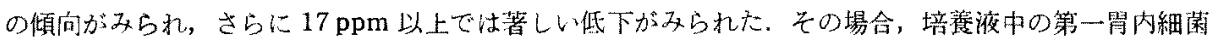

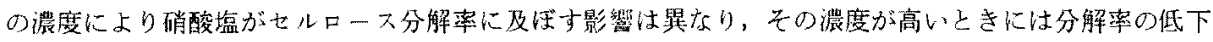

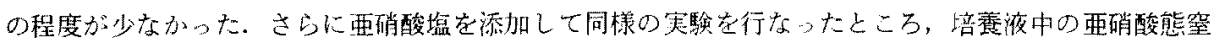
素䀼度が $5 \mathrm{ppm}$ 以上でセルロ一又分解率は明らかに抑制された。。
\end{abstract}

さきに行なた試験で，反解勳物に硝酸塩を投与する と，とくに硝酸中毒と思われる症状を現わさない程腐の 投与量でも，酳酸塩は增体や飼料利用性に悪影響をおよ

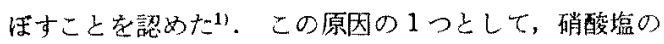

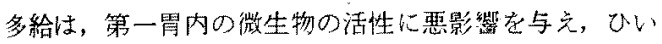
ては飼料の消化率索低下させるのではないかということ が考克ら机る。 HaLl ら 培養家行なったin vitroにおける観察で，硝酸塩や亚硝 酸壏の添加汇よって，七ルロースの消化率が加なり低下 したと報告している。

そこで本試験では，まず最初，硝酸塩在掑取したかん 羊において，飼料の消化率がどのようになるが索検討し 同時に窒素の出納についても検討した，つぎ牛の第一 胃内細菌によるセルロース分解能に及ぼす硝酸湓, 西硝

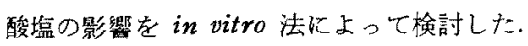

\section{試 験 方 法}

\section{1. 內久羊による消化試験}

供試動物乙しては, 体重䄪 $40 \mathrm{~kg}$ の去勢成め九羊を, 第一試䮖では3頙，第二試䮖では4 䫑用いた。本主第一 試驗では，それぞれ 17 日間の対县期之試駼期孝設け， 各期とも最初の 10 日間老予䚚飼育とし，その得 7 日間 採兴索行なった，対照期においては，第 1 表に示した基
Table 1. Composition of Basal Diets

\begin{tabular}{lcccc}
\hline & Exp. 1 & \multicolumn{2}{c}{ Exp. 2 } \\
\cline { 2 - 2 } \cline { 5 - 5 } & Diet 1 & Diet 2 & Diet 3 \\
\hline $\begin{array}{l}\text { Ingredients (g) } \\
\text { Wheat bran }\end{array}$ & 600 & - & 400 \\
Corn & - & 400 & 200 \\
Alfalfa meal & - & & 200 & 300 \\
Rice straw & - & 100 & 100 \\
Grass hay & 400 & - & - \\
Analysis (\%) & & & \\
Dry matter & 86.8 & 86.3 & 87.2 \\
Crude protein & 11.9 & 12.0 & 15.1 \\
Crude fat & 2.9 & 3.7 & 3.6 \\
Crude fiber & 17.1 & 11.1 & 12.8 \\
Nitrogen free extract & 49.9 & 54.7 & 50.1 \\
\hline
\end{tabular}

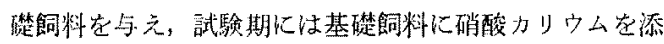
加した。硝酸力リウムの投与量俚 1 日当り 1 号年 $26.3 \mathrm{~g}$,

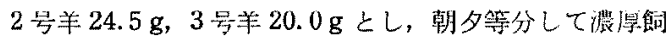
料に混じて与元た。妢盉料も朝多等分に給与した。排

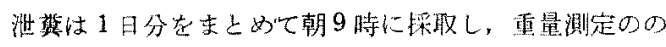

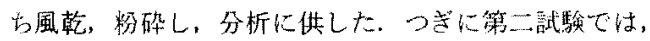
2 䫒ずつ2区に分け，1区には第 1 表に示寸飼料(2)苂， 
宮崎・岡本・津田・川島・上报

Table 2. Effect of Dietary Nitrate on Apparent Digestibilities of Ration Components (Exp. 1)

\begin{tabular}{lcccccccc} 
& \multicolumn{4}{c}{ Basal } & \multicolumn{3}{c}{ Basal plus nitrate } \\
\cline { 2 - 7 } \multicolumn{1}{c}{ Animal number } & 1 & 2 & 3 & Av. & 1 & 2 & 3 & Av. \\
\cline { 2 - 7 } Dry matter & 54.2 & 56.8 & 54.9 & $55.3^{\%}$ & 60.4 & 61.7 & 67.3 & 63.1 \\
Crude protein & 71.1 & 70.7 & 74.2 & 72.0 & 79.2 & 80.0 & 76.9 & 78.7 \\
Crude fat & 50.0 & 49.9 & 53.0 & 50.1 & 55.7 & 58.9 & 42.7 & 52.4 \\
Crude fiber & 26.9 & 37.9 & 33.6 & 32.8 & 43.0 & 44.9 & 46.5 & 42.3 \\
N.F.E. & 63.8 & 64.7 & 62.1 & 63.5 & 65.9 & 66.2 & 66.9 & 66.3 \\
\hline
\end{tabular}

2 区に注飼料(3)を与えて，对照期上試験期花設けて区転 法によって試験した，試䮖期に飼料に添加した酳酸力リ

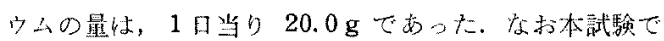

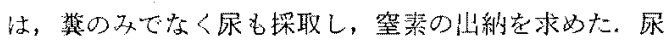
の探取にはトルェン索入れたビンを肺いた。

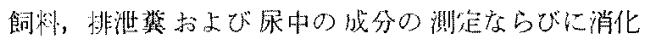

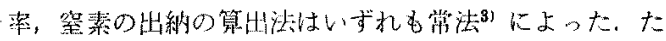

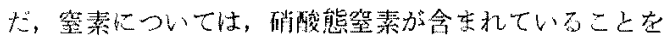

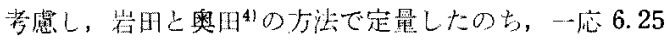
挆して粗たん白留として示した。

2. in vitro に上る七ル口-ス分解能測宝試雅

チモシ一乾草菢食させていた第一岗つィステル装着

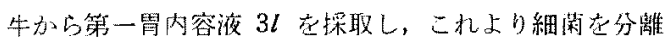
して, washed suspension 液 $1 l$ 在つくり，乙れ字 めセルロースハウダー $100 \mathrm{mg}$ と一定鼠の硝酸塩, 亜硝 酸塩を入れた大型試駼管内に分注し $20 \mathrm{~m} l$ 容とし，炭 酸がスを通じつつ, $39.5^{\circ} \mathrm{C}$ の恒温榑内で 24 時間培竞し た。拉，この操作は，いず执も当研究率で検討した人

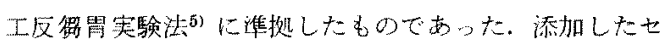
ルロースパウダーは，Carl Schleicher \& Schüll Zellulose Pulver 300 mesh 以上であった. 硝酸湓の添加量

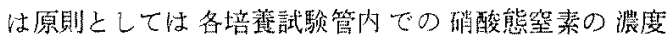
が, 1.73,8.66, 17.33,23.36, 46.72, 86.64 ppm と なるよう，硝酸かリウムを用いた。李た雪硝酸塩の添加 量は，同しく西酳酸態窒䋕の浱度が，0.99，5.00，10.00,

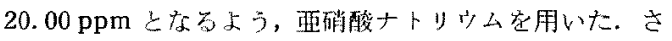
らに, washed suspension 肉の細菌源度を变支て，同

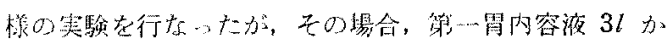

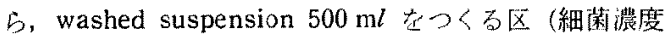

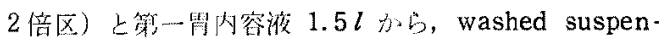

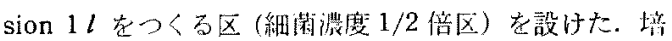

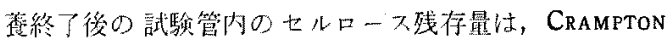

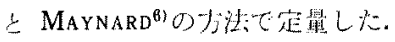

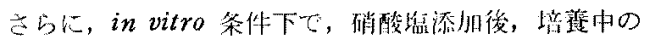

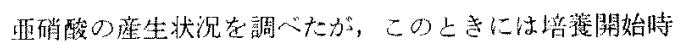

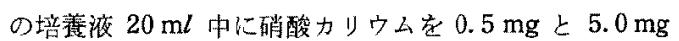
添加した。雨硝酸の定量は DIVEN ら゙のち法によった。

\section{試 験 結 果}

\section{1. めん羊による消化試験}

第一試駼：飼料(1)給与期におけるめん羊の見かけの消 化率を表示す机ば，第2 表のごとくである.

第 2 表に上れば，飼料に人為的に硝酸塩を添加したと き，粗たえ白貎，粗せえいの消化率は，対照期とくらべ て，备めん羊とむかなり高かった，可溶無窒素物につい

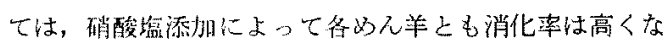
っていたが，その影粟の程度はごく少ない。また粗脂肪 の消化率は，硝酸笽の添加によって，10\%䯩くなった ものや，逆に 10\%汪ど低くなったものもあり，侗体に よる差異が大きかった。

第二試験：飼料(2)，飼料(3)給与期におけるめん羊の見 かけの消化率を一括表示ずれば，第 3 表, 第 4 表のごと くである.

第 3 表によれば，飼料(2)を給与されたとき，見かけの 消化率はめん羊個体ごとに差のある場合もあったが，平 均值て比較与れば，硝酸塩を添加した試験期において は，対照期とくらべて，粗たえ白質で約 $10 \%$, 乾物と可 溶無窒素物で $3 \%$ 程度消化率加高加った。しかし，他の 成分については，両期の間に差がはかった。

つぎに第 4 表によれば，飼料(3)を給与されたとき，見 がけの消化率は，これも平均值で比較すると，梢酸塩を 添加した期で，粗たん白質で $6 \%$ ，乾物で $2 \%$ 程度高か ったが，他の成分については，両期の間に差はなか。 t.

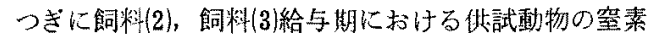
の出私について一括表示す札ば，第 5 表のごとくであ 3 .

第 5 丧によれ成，窒素排泚量は，兴中ではいずれの饲 料が与えられたとさでも，硝酸塩が添加されたとき，若

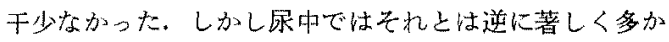


硝酸塩上消化率，七ルロース分解

Table 3. Effect of Dietary Nitrate on Apparent Digestibilities of Ration Components (Exp. 2 : Diet 2)

\begin{tabular}{|c|c|c|c|c|c|c|}
\hline \multirow{2}{*}{$\begin{array}{l}\text { Animal } \\
\text { number }\end{array}$} & \multicolumn{3}{|c|}{ Basal } & \multicolumn{3}{|c|}{ Basal plus nitrate } \\
\hline & 4 & 5 & Av. & 4 & 5 & Av. \\
\hline Dry matter & 73.0 & 69.7 & $\begin{array}{r}\% \\
71.4\end{array}$ & 75.0 & 74.7 & $\begin{array}{r}\% \\
74.9\end{array}$ \\
\hline Crude protein & 66.9 & 58.6 & 62.8 & 73.1 & 71.6 & 72.4 \\
\hline Crude fat & 79.8 & 80.7 & 80.3 & 80.9 & 82.3 & 81.6 \\
\hline Crude fiber & 42.9 & 38.0 & 40.5 & 40.4 & 41.5 & 41.0 \\
\hline N.F.E. & 86.6 & 81.5 & 83.1 & 87.0 & 85.9 & 86.5 \\
\hline
\end{tabular}

Table 4. Effect of Dietary Nitrate on Apparent Digestibilities of Ration components (Exp. 2 : Diet 3)

\begin{tabular}{|c|c|c|c|c|c|c|}
\hline \multirow{2}{*}{$\begin{array}{l}\text { Animal } \\
\text { number }\end{array}$} & \multicolumn{3}{|c|}{ Basal } & \multicolumn{3}{|c|}{ Basal plus nitrate } \\
\hline & 6 & 7 & Av. & 6 & 7 & Av. \\
\hline Dry matter & 69.3 & 68.8 & $\begin{array}{r}\% \\
69.1\end{array}$ & 71.8 & 71.5 & $\begin{array}{r}\% \\
71.7\end{array}$ \\
\hline Crude protein & 72.9 & 71.7 & 72.3 & 79.5 & 77.5 & 78.5 \\
\hline Crude fat & 73.9 & 72.6 & 73.3 & 4.7 & 73.9 & 74.3 \\
\hline Cruce fiber & 42.9 & 39.5 & 41.2 & 43.7 & 41.9 & 42.8 \\
\hline N.F.E. & 79.5 & 79.6 & 79.6 & 80.9 & 80.9 & 80.9 \\
\hline
\end{tabular}

Table 5. Effect of Dietary Nitrate on Nitrogen Balance (Exp. 2)

\begin{tabular}{lcccccc}
\hline & \multicolumn{3}{c}{ Diet 2} & & \multicolumn{2}{c}{ Diet 3 } \\
\cline { 3 - 6 } & & Basal & \multicolumn{1}{c}{$\begin{array}{c}\text { Basal } \\
\text { plus } \\
\text { nitrate }\end{array}$} & Basal & $\begin{array}{c}\text { Basal } \\
\text { plus } \\
\text { nitrate }\end{array}$ \\
\hline Nitrogen intake, & g. & 13.42 & 16.19 & 24.21 & 27.81 \\
Nitrogen in feces, & g. & 5.01 & 4.48 & 6.70 & 5.99 \\
Nitrogen in urine, & g. & 2.67 & 5.06 & 6.60 & 8.59 \\
Nitrogen retained, & g. & 5.75 & 6.65 & 10.91 & 13.23 \\
Nitrogen retained as & 42.8 & 41.1 & 45.1 & 47.6 \\
percent of intake, $\%$ & & & & &
\end{tabular}

Table 6. Effect of Nitrate on in vitro Cellulose Digestibility by Rumen Microorganisms

\begin{tabular}{|c|c|}
\hline $\begin{array}{l}\text { Nitrate nitrogen } \\
\text { concentrations }\end{array}$ & Cellulose digestibility \\
\hline $\mathrm{ppm}$ & $79.7 \pm 6.0^{\%}$ \\
\hline 1.73 & $74.1 \pm 4.5$ \\
\hline 8.66 & $65.1 \pm 8.7$ \\
\hline 17.33 & $26.9 \pm 6.0$ \\
\hline 23.36 & $20.6 \pm 2.2$ \\
\hline 46.72 & $20.0 \pm 0.1$ \\
\hline 86.64 & $12.5 \pm 3.0$ \\
\hline
\end{tabular}

Table 7. Effect of Nitrate on in vitro Cellulose Digestibility by Rumen Microorganisms (Initial microbe concentrations: $200 \%$ )

\begin{tabular}{cc}
\hline $\begin{array}{c}\text { Nitrate nitrogen } \\
\text { concentrations }\end{array}$ & Cellulose digestibility \\
\hline $0 \quad \mathrm{ppm}$ & $83.8 \pm 10.0^{\%}$ \\
1.73 & $79.2 \pm 12.2$ \\
8.66 & $78.5 \pm 11.0$ \\
17.33 & $72.8 \pm 7.1$ \\
23.36 & $73.6 \pm 0$ \\
46.72 & $53.6 \pm 2.2$ \\
86.64 & $22.2 \pm 9.6$ \\
\hline
\end{tabular}

Table 8. Effect of Nitrate on in vitro Cellulose Digestibility by Rumen Microorganisms (Initial microbe concentrations: $50 \%$ )

\begin{tabular}{cc}
\hline $\begin{array}{c}\text { Nitrate nitrogen } \\
\text { concentrations }\end{array}$ & Cellulose digestibility \\
\hline $0 \quad p p m$ & $76.7 \pm 3.4$ \\
4.67 & $71.1 \pm 10.0$ \\
9.29 & $31.2 \pm 20.0$ \\
23.36 & $17.4 \pm 8.2$ \\
77.63 & $18.3 \pm 5.0$ \\
\hline
\end{tabular}

った、つぎに窒素保留量は，硝酸喤が添加された期で，

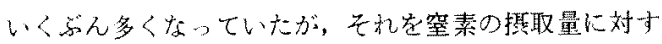

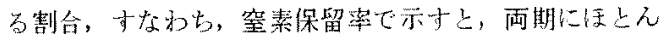
ど羞はなかった。

2. in vitroに上る七ルロース分解能測定試駰

硝酸塩の添为が第一霄内細菌によるセルロー又分解能 に及ほす影節定示せば，第6 表のごとくである。

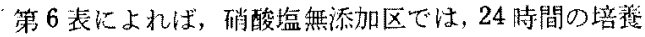
期聞中のセルロース分解率は $80 \%$ とかなり扈かった。 しかし，硝酸湓が添加された区で忹，添加量が多くなる につれて分解染が低下した。 とくに堷徨液中 $8.66 \mathrm{ppm}$ ○硝酸態窒素が含まれているとき，セルロ一スは $65 \%$ 分解されたが， $17.33 \mathrm{ppm}$ 以上のときには，20\% 前後 李で分解率は低下した。

つぎに培葆開始時に細菌浱度を変えた場合の，硝酸塩 添加が，セルロース分解能に及法影留を示せば，第 7 表，第 8 表のごとくである.

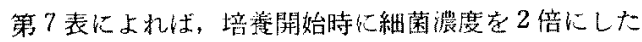
とき，酳酸塩添加が第一胃内細菌によるセルロ一又分解

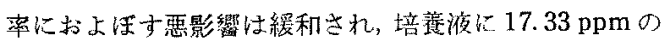
硝酸態窒素が含丈れているときにも，セルロースは $73 \%$ も分解された。 さらに $46.72 \mathrm{ppm}$ の場合でも，分解率 
宮崎・岡本・津田・川島・上坂

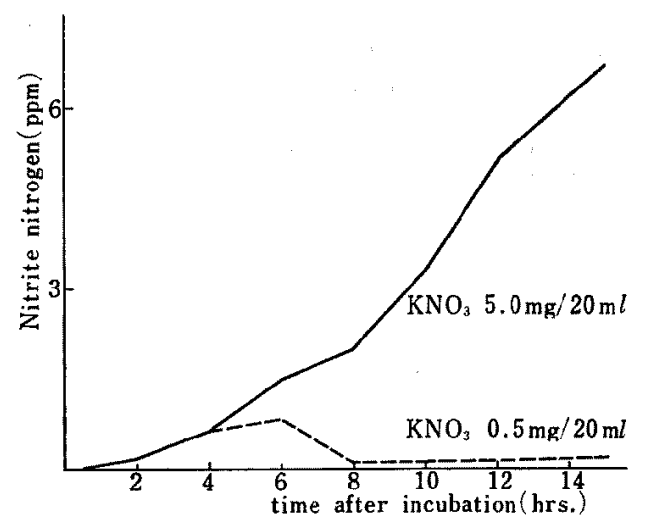

Fig. 1. Nitrite Accumulation during Incubation after Introducing $0.5 \mathrm{mg}$ and $5.0 \mathrm{mg}$ Potassium Nitrate into $20 \mathrm{~m} l$ tube

Table 9. Effect of Nitrite on in vitro Cellulose Digestibility by Rumen Microorganisms

\begin{tabular}{|c|c|}
\hline $\begin{array}{l}\text { Nitrite nitrogen } \\
\text { concentrations }\end{array}$ & Cellulose digestibility \\
\hline ppm & $79.7 \pm 2.6^{\%}$ \\
\hline 0.99 & $80.9 \pm 4.7$ \\
\hline 5.00 & $63.4 \pm 8.7$ \\
\hline 10.00 & $47.8 \pm 5.7$ \\
\hline 20.00 & $11.8 \pm 1.5$ \\
\hline
\end{tabular}

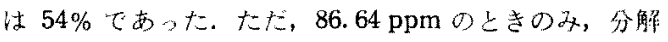
装は $22 \%$ とが抑制された。

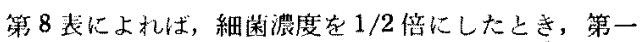

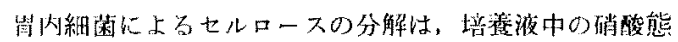
空素浱度が $9.29 \mathrm{ppm}$ のとき, $31 \%$ と抑制され，さら に多くの酳酸塩が添加されると，七ルロース分解率の低 下はさらに顕著になった。

さて，硝酸塩を培着試験管内に入れると，還元されて

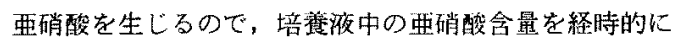
測定寸れは，第 1 图のごとくてある.

第 1 図によれば，培養開始後，培養液中で亜硝酸態空 素が次符に增加する。培盖開始時の硝酸カリウム添加量 が $0.5 \mathrm{mg}$ の場合には, 培䕐 6 洔間後に西硝酸含量は最 大となり，その後急速に隇少し，8時間以降ではほ己ん ど検出されなくなった.しかし，5.0 mg 添加の場弇に は，堮鉒 15 時間後まで，要硝酸含量は多くなりつつあ り，この測定範囲内では，15 㭙間目に覀硝酸態窒素の濃 度は $6.70 \mathrm{ppm}$ となり最大值を示した。

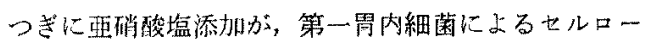

ス分解率におよぼす影響它示せば，第9表のごとくであ る.

第9 表によれば，覀硝酸塩の添加も，セルロース分解 率定低下させる.とくに亚硝酸態窒菜濃度が $20.00 \mathrm{ppm}$ の上きには，セルロース分解率は $12 \%$ と著しく抑制さ れた.

考察

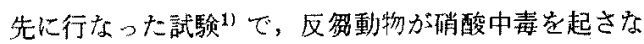
いが，增体き $1 \mathrm{~kg}$ 增体に要寸る飼料の DCP，TDNに

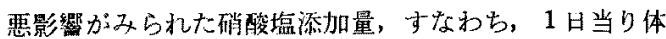
重の $0.05 \%$ 程度の硝酸力リウムを飼料に添加して消化 率を調べたところ，めん羊の見かけの消化率に忹何ら惠 影很がみられず，むしろ見かけの消化率は，飼料に硝酸 塩を添加した場合の方が，いくやかの成分について，む しろ高くなった。これを各試験における平均值でみる 々，消酸熄が添加された場合には，無添加期とくらべ， 乾物で 2.6〜7.6\%，粗た九白質で 6.2〜9.6\% も高くな り，少なくとも試験前に予測したような，硝酸熄が飼料 の消化率莛低させるということはないようであった。

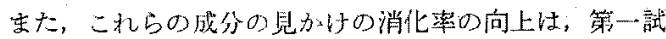
䮖でとくに顕著であった。しかし，その他の成分につい ては，第一試験で粗せんいの消化率が硝酸垍添加時に高

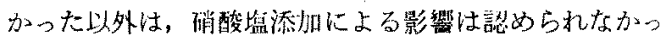
た。

従来，非たん白態窒素化合物を飼料に添加したとき， それが見かけの消化率に及ぼす影響については，多くの

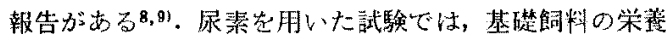
水準の如何にかか加らず，乾物，有機物，“粗たん白質和 よび粗せんいの見かけの消化蛙は，加なり高くなること が報告されている81.この点, 本試験の結果は, 粗せん いの消化率を除くと，それらの成觼に符合しているよう でるる。さて，第5表によれば，硝酸塩を添加したと き，顀中八の窒素排泄量は，然添加期より少ない。これ は硝酸塩の添加によって，基礎飼料中に含まれていた空 素成分の真の消化率加よくなったのか；または，筀素の 再排出量が減少したのかの2つの場合が考点られる，硝 酸カリウムは利丞剂としての薬理作用家有するものです るので10，血液中からの空素化合物の除去を盛えにし， ひいては，消化管内加ら，上り多くの掌菜成分が吸収さ れたか，史た洅排出它少なくしたのかもしれない，一 方，硝酸境が添加されたとき，氺中に著しく多くの空䕀 が排泟された，粗たえ白質の見かけの消化率が高くでた のは硝酸塩中の空素の多くが尿中に出たためでるろう。 全体として空素の出納家み当と，飼料(2)，飼料(3) 給与 
期のいずれにおいても，硝酸塭の添加によって，供試動 物の体内の空素保留量は多くなっており, 窒素の摄取量 に対する保留量は，いずれの飼料崖与えられたときにる 大差なかった、したがって，給与された碈酸態窒秦は， 基礎飼料のたん白啠上ほぼ同程度に動物に利用されたこ と意味していると思われる，てうして，少なくとも硝 酸塩の添加が窒索の消化や出納にとくに悪影暗を及ほす ものとは考光られないようである。

つぎに粗せえいの見かけの消化率は，第一試験におい てのみ，硝酸塩添加時に $9.5 \%$ 高加た，第一試験て は第二試験とくらべて，乾草を多く給与していたので， 飼料の粗せんい含量が多加った、GALLUP ら日1によれば， 乾草多く含む飼料が与えられていると，尿素の添加に よって粗せんいの見加けの消化率は $10 \%$ も高くなった ということであり, 乾草它多く与えた場合には硝酸㦈も 尿素と同じ上うな㗢きで見か子の消化率よくするのか もしれない.しかしこの結果は，才ーチャードグラスの 乾草の粉末に $2.5 \mathrm{~g}$ と $5.0 \mathrm{~g}$ の硝酸ナトリウムを添加し たとき，めえ羊の消化率が乾物とセルロースについて， 無滋加区より有意に低かったという HALL らの成緽と は第盾していた。乾草を粉末にしてめん跲に給与した埸 合には消化管內ての移動も早くなるし，またその試䮖 では硝酸㦈の添加量もごく少ないものであったために， その上うな結果がえられたものであるう。ちなみに同報 告2には、追試したときに消酸塩の影響がみられなか ったと述べられていた，さらには，津田ら"11によれば， 分寸をを多く含む飼料を摄取しためん羊の第一胃内で硝 酸の還汇がとくに早いようであり，体重当り $0.05 \%$ ○

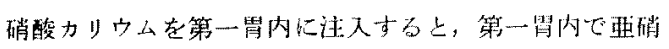

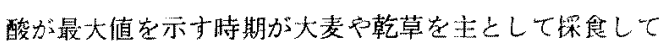
いるめえ羊では飼料掑取後 3〜5 時間目であったのに， ふ寸まを採食している動物ではそれが2时䅦後であった というので，第一試験ではふすす劣多く給与していたの で硝酸の消失が早く，したがって粗せ九いの消化に及ぼ 才影㗽が悪くなかったのかもしれない。

さらに，牛の第一罥内細菌を㸨いて，七ル口ース分解

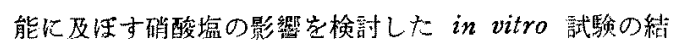

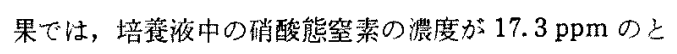
きには，七ルロースの分解が著しく少なくなり，然添加 区では $80 \%$ 近くまで分解されていたのに対し, 添加区

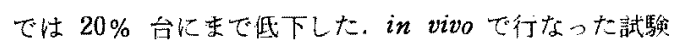
で，第一霄内に体重の $0.05 \%$ の硝酸カリウムを添加し た場合の捎酸態窒素の濃度老，第一男内容液の概算量か ら算定すると，100 ppm 以上にも及んでいるが，この濃 度です粗せんいの消化桃にはとくに悪影響がみられてい
ない、これについては，牛とめん羊という動物分類学上 の位置の賞いに上る影響とも考えられようが，てれだけ で説明するには差が大きすぎる上うである。これについ

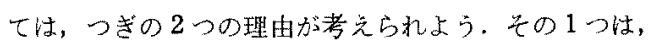
in vivoではin vitroと異なり，第一罥壁を通しての捎 酸の昅収が里く，しか禹盛んなことであろう。かって著 者は19，in vivoで投与された硝酸湓は，投与 1.5 時間 後に，めん羊の第一罩内には多めに見積っても，50\%以 下のものしか検出されないこと萑認奻た，そのとき，こ の上うに早い硝酸の消失は，硝酸が還䒕されたためだけ ではなく、大部分が硝酸イオンとして血被中に移行与る ためであるかのご上き結贸を克た。この财収といら現象

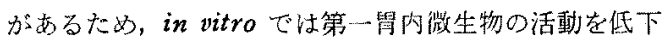
させる程度の硝酸塩があってす，in vivo では著しい障 害が起きないのであるう。さらにもう1つの理由は，in vitro とin vivo とでは，第一舅内微生物の種類上数とが 異なることであるう。こ机は，培盖開始時に細菌の濃度

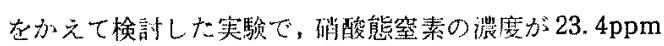
のとき，2解区ではセルース分解染が $73.6 \%$ であっ たのに，1/2 倍区ではそれが $17.4 \%$ てあったことから

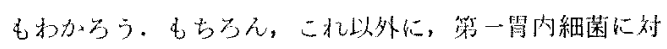
する售分供給の条件にも，in vitro 上 in vivo 上では㾏 があるに堂いない，ともあれ，in vitroでは，七ル口一

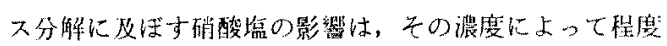
に差こてあれ，セルロースの分解寡客问上させるものて はなさそうである。

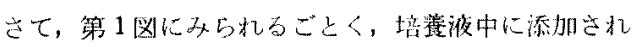

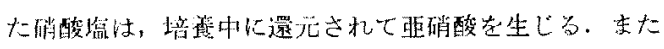

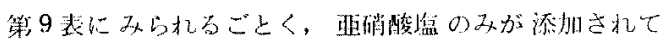
も，七ルロース分解能が抑制される。したがって第一青

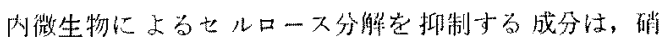

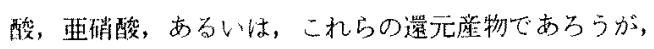
本試験では，それがいずれの成分であったのかは明らか ではない。

結局，in vivoて，粗せんいの見かけの消化舜が捎酸 塩の港加によって，とくに悪くならないことと, in vitro でのセルロース分解が硝醡䘏の添加によって悲くなるこ ととの間には榆討要するいるいるな閶題があるのであ

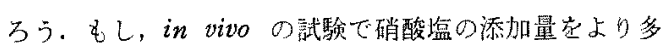
くすれば，粗せんいの消化にも影籍が出るであららを思 われるが，その場合には血淮中のメトへモグロビン形成 が多くなって，他の面での影端が大きな閶题となるう。

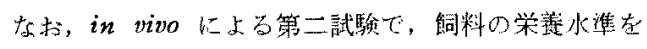
变えて，硝酸塩添加の影響をみたが，この上うな条件下 では判然とした傾向は該められなかった。 


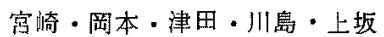

終りに臨み，実駼の实施に当り有益な助言をいただい

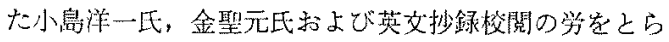
れた神谷俊郎氏に語えで感誹の意を表する．また動物の

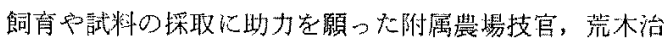
三郎氏，藤原勇氏，佐波嘉夫氏に曆く御礼申し上げる。

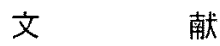

1）宮酠 昭，日蓄会報 38：527一536, 1967.

2) HaLl, O.G., J. BARTh, and C.S. HobBS, J Anim Sci 17: 1206.1958.

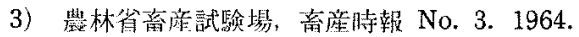

4）薂田武司 - 奥田 東，日土肥誌 12：90-92. 1938.

5）上坂章次・川島良治・坢田義治・目淵春三，京大 食研報告 26：1-16. 1962 .
6) Crampton, E. W., and L. A. Maynard, J Nutr 15: 383-395. 1938.

7) Diven, R. H., W. J. Pistor, R.E. Reed, R. L. Trautman, and R.E. Watts, Amer J Vet Res 23: 497-499. 1962.

8) Gallup, W.D., L.S. Pope, and C.K. WhiteHAIR, J Anim Sci 11: 621-630. 1952.

9) Anderson, G. C., G.A. McLaren, J.A. Wezch, C.D. Campbeld, and G.S. Smith, J Anim Sci 18: 134-140, 1959.

10) Garner, G.B., Proc N Z Soc Anim Prod 23: 28-38. 1963.

11) 津田栄三・井上明、上坂幛次，日窗学会関西支 部報 48：19. 1967.

12）宮崎 鳃，末発琵。

\title{
Effect of Dietary Nitrate on the Feed Digestibility in Ruminants
}

\author{
Akira Mryazaki, Kazuo Okamoto, Eizo Tsuda, \\ Ryoji Kawashima and Shoji Uesaka \\ College of Agriculture, Kyoto University, Kyoto-shi 606
}

The first experiment was carried out in vivo to study the effect of dietary nitrate on feed digestibility and nitrogen balance of the ruminants. Seven Japanese Corriedale wethers, about $40 \mathrm{~kg}$ in body weight, were used. All animals were placed in the digestion crate and were fed twice daily. Before the treatment period, all feces and urine were collected for seven days to obtain data as controls. Potassium nitrate of $0.05 \%$ of body weight was mixed with concentrate ration and was given to the animals for seventeen days. The last seven days, total feces and urine samples were collected and studied feed digestibility and nitrogen balance. It was observed that dietary nitrate seemed to improve the apparent digestibility of dry matter and crude protein as much as 2.6 to $7.6 \%$ and 6.2 to $9.6 \%$ respectively. However, nitrogen retention was not improvied by dietary nitrate. Excretion of nitrogen into urine increased and effect of nitrate on crude fiber, crude fat and N.F.E. digestibility was not apparent. To study the effect of nitrate on cellulose digestion by bovine rumen microorganisms in vitro, an artificial rumen described by UESAKA et al. ${ }^{5)}$ (1962) was used. Nitrate nitrogen concentration in the washed suspension fluid were set as follows; $1.73,8.66$, 17. $33,23.36,46.72,86.64 \mathrm{ppm}$. When nitrate was not added to the rumen fluid, $80 \%$ of purified cellulose was digested during 24 hour fermentation. The higher the nitrate concentration was, the lower the cellulose digestibility was. The relationships between the amount of nitrate and cellulose digestibility were as follows; nitrate nitrogen $8.66 \mathrm{ppm}$, cellulose digestibility $65 \% ; 17.33 \mathrm{ppm}, 27 \% ; 23.36 \mathrm{ppm}, 21 \% ; 46.72 \mathrm{ppm}, 20 \%$ and $86.64 \mathrm{ppm}, 12.5 \%$ respectively. When the concentration of rumen microorganisms was halved, nitrate seemed to depress the cellulose digestibility and it was lowered to $31 \%$ even at $8.66 \mathrm{ppm}$. On the other hand, when the concentration of microorganisms was doubled, the effect of nitrate seemed to be reduced. Cellulose digestibility was around 73 to $80 \%$ up to $23.36 \mathrm{ppm}$ of nitrate, but it went down to $20 \%$ at $86.64 \mathrm{ppm}$. 